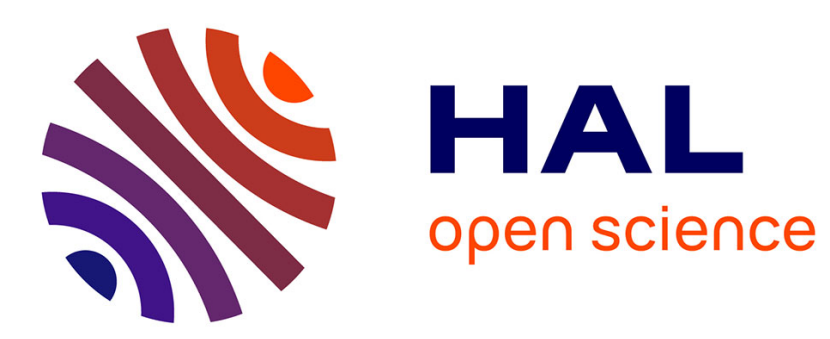

\title{
Calcium signalling at fertilization
}

Karl Swann, Alex Mcdougall, Michael Whitaker

\section{To cite this version:}

Karl Swann, Alex Mcdougall, Michael Whitaker. Calcium signalling at fertilization. Journal of the Marine Biological Association of the UK, 1994, 74 (1), pp.3-16. 10.1017/S002531540003561X . hal03025646

\section{HAL Id: hal-03025646 https://hal.science/hal-03025646}

Submitted on 16 Dec 2020

HAL is a multi-disciplinary open access archive for the deposit and dissemination of scientific research documents, whether they are published or not. The documents may come from teaching and research institutions in France or abroad, or from public or private research centers.
L'archive ouverte pluridisciplinaire HAL, est destinée au dépôt et à la diffusion de documents scientifiques de niveau recherche, publiés ou non, émanant des établissements d'enseignement et de recherche français ou étrangers, des laboratoires publics ou privés. 


\title{
CALCIUM SIGNALLING AT FERTILIZATION
}

\author{
KARL SWANN*, ALEX MCDOUGALL ${ }^{+}$AND MICHAEL WHITAKER ${ }^{\dagger}$ \\ *MRC Experimental Embryology and Teratology Unit, St George's Hospital Medical School, Cranmer \\ Terrace, London, SW17 ORE. 'Department of Physiology, University College London, Gower Street, \\ London, WC1E 6BT (address correspondence to M. Whitaker).
}

It is generally agreed that fertilization in deuterostomes is accompanied by a large intracellular calcium wave that triggers the onset of development, but we still do not know exactly how the calcium wave is generated. The question has two parts: how does interaction of sperm and egg initiate the calcium wave, and how does the calcium wave spread across the cell? Two provisional answers are available to the first part of the question, one involving receptor-G-protein interactions of the sort that mediate transmembrane signal transduction in somatic cells, the other injection of an activating messenger when sperm and egg fuse. Both these ideas are being actively pursued; the dialectic is productive, albeit no synthesis is in sight. We discuss their strengths and weaknesses. The second part of the question can now be much more precisely formulated: thanks to the recent flush of interest in calcium waves in somatic cells, new ideas and new experimental tools are available. The work on somatic cells repays a debt to eggs, where the basic properties of calcium waves were first set out, ten years before they turned up in somatic cells.

\section{INTRODUCTION}

In deuterostomes, the fertilizing sperm triggers a calcium increase within the egg that travels as a wave from the point of sperm-egg interaction to its antipode (Jaffe, 1980; 1983). The calcium wave activates the egg and is necessary and sufficient as a signal to trigger the onset of development (Steinhardt et al., 1974; Lorca et al., 1991; see Whitaker \& Steinhardt, 1982, and Whitaker \& Patel, 1990, for reviews). But we should not forget the sperm. The incorporation of the sperm nucleus into the egg cytoplasm is an essential element of syngamy and maintenance of diploidy. What we shall discuss here is the link between egg activation and sperm egg fusion. The link is a strong one: except in very special circumstances (Longo, 1978; Chambers, 1989) an egg is never activated after insemination without at the same time incorporating a sperm. How is the link forged?

Looked at from the sperm's point of view, there are two obvious strategies for gaining entry. The well-bred sperm might knock on the door and wait for the egg to respond. A less delicate strategy is to barge in without bothering to ring. The first of these strategies finds a physical realization in the idea of G-protein-mediated transmembrane signalling. On this hypothesis (Jaffe et al., 1988), the sperm interacts with a G-protein-linked membrane receptor to generate an intracellular message that triggers the calcium wave, fusion of the sperm and egg plasma membranes, and sperm incorporation. It waits for 
an answer. The less genteel strategy corresponds to an older idea from rougher times (Jaffe, 1983), where, without waiting for a by-your-leave, the sperm fuses with the egg, so injecting an activating messenger that sets off the calcium wave. These two usefullycontrasting ideas form the basis for a discussion of the cellular messengers and mechanisms that generate the fertilization calcium wave. We shall discuss only data from frog, mouse, hamster and sea urchin eggs.

\section{KNOCK AND THE DOOR WILL BE OPENED}

The idea that a G-protein signal transduction system might operate at fertilization had its beginnings in the discovery of a polyphosphoinositide (PPI) messenger system in eggs (Turner et al., 1984; Whitaker \& Irvine, 1984) and grew alongside the discoveries that GTP binding proteins linked receptor proteins to generation of the PPI messengers inositol trisphosphate ( $\mathrm{InsP}_{3}$ ) and diacylglycerol (DAG).

\section{PPI messengers at fertilization}

There is a marked increase in the turnover of the PPI lipids at fertilization in sea urchin eggs (Turner et al., 1984; Ciapa et al., 1992), the hallmark of activation of the PPI signalling system. Both $\mathrm{InsP}_{3}$ and DAG are produced during the fertilization calcium transient or after activation of eggs with calcium ionophore (Ciapa \& Whitaker, 1986; Ciapa et al., 1992) and sea urchin eggs have a calcium-dependent phosphoinositidase $C$ that may be responsible for this (Whitaker \& Aitchison, 1985). Micro-injecting InsP triggers the calcium wave and activates sea urchin (Whitaker \& Irvine, 1984), frog (Busa et al., 1985) mouse (Kurasawa et al., 1989; Kline \& Kline, 1992; Swann, 1992) and hamster eggs (Miyazaki, 1988; Cran et al., 1988). In sea urchins, the calcium wave is independent of external calcium (Crossley et al., 1988), implying release of calcium from an internal store. Indeed, sea urchin homogenates have a non-mitochondrial $\mathrm{InsP}_{3}$-sensitive calcium sequestration system (Clapper et al.,1987) that has its counterpart in the endoplasmic reticulum of the intact egg (Henson et al., 1989, 1990; Terasaki et al., 1991; Terasaki \& Sardet, 1991). A similar set of results is obtained from frog egg homogenates (Galione et al., 1992).

Sea urchin eggs, then, have a functioning PPI messenger system at fertilization. Some or all of the $\mathrm{InsP}_{3}$ and DAG produced at fertilization is a consequence of the calcium increase, not a cause. Data from frog and hamster eggs suggests that they are analogous, but is not extensive: no measurements of PPI turnover have been made. How comfortably can we sustain the view that $\mathrm{InsP}_{3}$ triggers or facilitates the calcium wave at fertilization? With ease in hamster and frog eggs, where blocking the $\mathrm{InsP}_{3}$ receptor [InsP ${ }_{3} R$ ] (Miyazaki et al., 1992; Galione et al., 1992) prevents the intracellular calcium wave. Less happily in sea urchin eggs, where the $\operatorname{Ins}_{3} \mathrm{R}$ antagonist, heparin, fails to block the calcium wave (Rakow \& Shen, 1990; Crossley et al., 1991; Galione et al., 1993; Lee et al., 1993). We shall return to this; differences between eggs that have calcium waves with apparently identical properties (Jaffe, 1983) is one of the themes of this survey. 


\section{The sperm, the receptor and $G$ proteins}

The receptor proteins that mediate sperm-egg binding in sea urchin and guinea pig have been characterized (Foltz \& Lennarz, 1990, 1992; Blobel et al., 1992); for guinea pig, primary sequence data are available and the receptor shows homology to integrin receptors. Is there a link with signal transduction? Integrin receptor occupancy has been shown to lead to the generation of calcium signals (Jaconi et al., 1991), perhaps by stimulating tyrosine kinase activity (Kornberg et al., 1991), and tyrosine kinase activity can trigger PPI turnover via phospholipase $\mathrm{C} \gamma$ (Rhee, 1991). Note, though, that integrin receptors do not interact, as far as is known, with the multimeric $\mathrm{G}$ proteins. The sequence data for the sea urchin sperm-receptor protein shows no obvious homology with any signal-transducing receptor (Foltz et al., 1993), but activation of a tyrosine kinase precedes the fertilization calcium transient (Ciapa et al., 1991), a finding that at least raises the possibility of tyrosine-kinase-linked signal transduction. The idea of a Gprotein-linked signal transduction system at fertilization does not gain much support from what is known about the receptor side of things. Its strengths lie in another quarter.

Trimeric GTP binding proteins are activated by guanosine 5 -triphosphothioate (GTP $\gamma$ S) and so are sea urchin (Turner et al., 1986), hamster (Miyazaki, 1988) and frog eggs (Kline et al., 1991). Proteins ribosylated by cholera and pertussis toxins (toxins with G-protein targets) can be identified in sea urchin egg plasma membrane (Turner $e$ t al., 1987). Cholera toxin activates sea urchin eggs (Turner et al., 1987) but pertussis toxin does not inhibit fertilization in sea urchin (Turner et al., 1987), frog (Kline et al., 1991), starfish (Shilling et al., 1989) or hamster (Miyazaki, 1988). The initial successes with GTP $\gamma$ S encouraged the elegant approach of injecting brain mRNA-derived cDNA, and cDNA coding for the G-protein-linked 5-HT receptor, into oocytes (Kline et al., 1988; Shilling et al., 1990). When the oocytes matured, they had incorporated the receptors themselves into the egg membrane. Adding 5-HT triggered a fertilization-like calcium transient and egg activation. In mammalian eggs, there is no need for experiments with receptor cDNA: there are G-protein-linked 5-HT receptors in the hamster (Miyazaki et al., 1990) and G-protein-linked acetylcholine receptors in the mouse (Swann, 1992) that generate calcium oscillations. This latter fact did not discourage Williams et al. (1992) from introducing mRNA coding for the ACh receptor into mouse oocytes to show that ACh application would activate eggs. These and the GTP $\gamma$ experiments amply demonstrate that eggs have a G-protein-linked PPI messenger system, a pre-requisite if the Gprotein mechanism is to operate at fertilization. The $G$ proteins are sufficient to evoke a fertilization-like calcium transient, but are they necessary?

Proving that G-proteins are necessary at fertilization has been more difficult. One tool used has been GDP $\beta S$, an inhibitory guanine nucleotide analogue. GDP $\beta S$ was originally reported to block elevation of the fertilization envelope in sea urchin egg after insemination (Turner $e t$ al., 1986), a result taken to imply that $G$ proteins were necessary for the fertilization response. Subsequently it was shown that GDP $\beta S$ blocked only envelope elevation, not the fertilization calcium transient (Crossley et al., 1991); the latter outcome turns the meaning of the experiment on its head, indicating that $G$ 
proteins do not mediate the fertilization response. Recall that the fertilization calcium transient in sea urchin eggs is not blocked by the $\mathrm{InsP}_{3} \mathrm{R}$ antagonist heparin; the GTP $\gamma \mathrm{S}$ induced calcium transient is (Crossley et al., 1991). The simplest interpretation of these data is that while GTP $\gamma S$ triggers a calcium transient by generating $\operatorname{InsP}_{3}$, the sperm does not. The G-protein idea also predicts that production of InsP $\mathrm{P}_{3}$ and DAG is the result of receptor occupancy. However, if sea urchin eggs are inseminated after microinjecting the calcium chelator BAPTA, no DAG production is detectable (Crossley et al., 1991), apparently indicating that the production of the PPI messengers is the result, rather than the cause of the calcium increase. All the experiments designed to test whether $G$ proteins are essential for signal transduction at fertilization in sea urchin eggs have so far come up negative. In the hamster egg, things are a little better.

In hamster eggs, micro-injecting GDP $\beta S$ has been shown to block the calcium response at fertilization, without affecting Ins $\mathrm{P}_{3}$-induced calcium release from the egg's internal store (Miyazaki, 1988). Thus, there is evidence that, in hamster eggs, $G$ proteins may be necessary for fertilization signal transduction. This is the only piece of evidence in any egg that points to an essential role for $G$ proteins at fertilization. Even for hamster eggs, this pure-seeming proof is not unalloyed, as the following experiments demonstrate. Treating hamster eggs with phorbol ester mimics the natural down regulation of the receptor-G-protein response (in this it differs from the fertilization response, which does not down regulate: Swann et al., 1989; Miyazaki et al., 1990) and inhibits the series of calcium transients that usually follow injection of GTP $\gamma$ S (Swann et al., 1989); the fertilization calcium transients are unaffected. The sperm is clearly not behaving like GTP $\gamma$ S. If these latter experiments are accepted as evidence against the G-protein idea, then the inhibition of fertilization by GDP $\beta S$ has to be explained away. In frog oocytes, GDP $\beta S$ blocks all but the first of a series of calcium transients that can be generated by $\mathrm{InsP}_{3}$ (Sealfon et al., 1990), perhaps because $\mathrm{G}$ proteins are involved in the translocation of calcium from one internal store to another (Ghosh et al., 1989). This is one way to explain inhibition of fertilization by GDP $\beta$, but it is not a very compelling argument. We are left with a clear contradiction between the two sets of experiments in hamster eggs.

To sum up for $G$ proteins: there is abundant evidence for a G-protein-linked PPI messenger system in eggs that, when stimulated, will bring about egg activation; it is much less certain that the mechanism necessarily operates at fertilization. The worst case is the sea urchin egg, where neither GDP $\beta S$ nor heparin blocks the fertilization calcium wave. The best case is the hamster egg where blocking either $G$ proteins or the Ins $\mathrm{P}_{3} \mathrm{R}$ can prevent the fertilization calcium transient. But even in hamster, the fact that the response to GTP $\gamma S$ can be down regulated without affecting the fertilization response should make us cautious about swallowing the bait whole.

\section{Opening the door}

How do we explain sperm-egg fusion and sperm incorporation if the sperm first interacts with a G-protein-linked transmembrane receptor? Sperm-egg fusion has not received much attention in the context of the G-protein model. Our simple analogy 


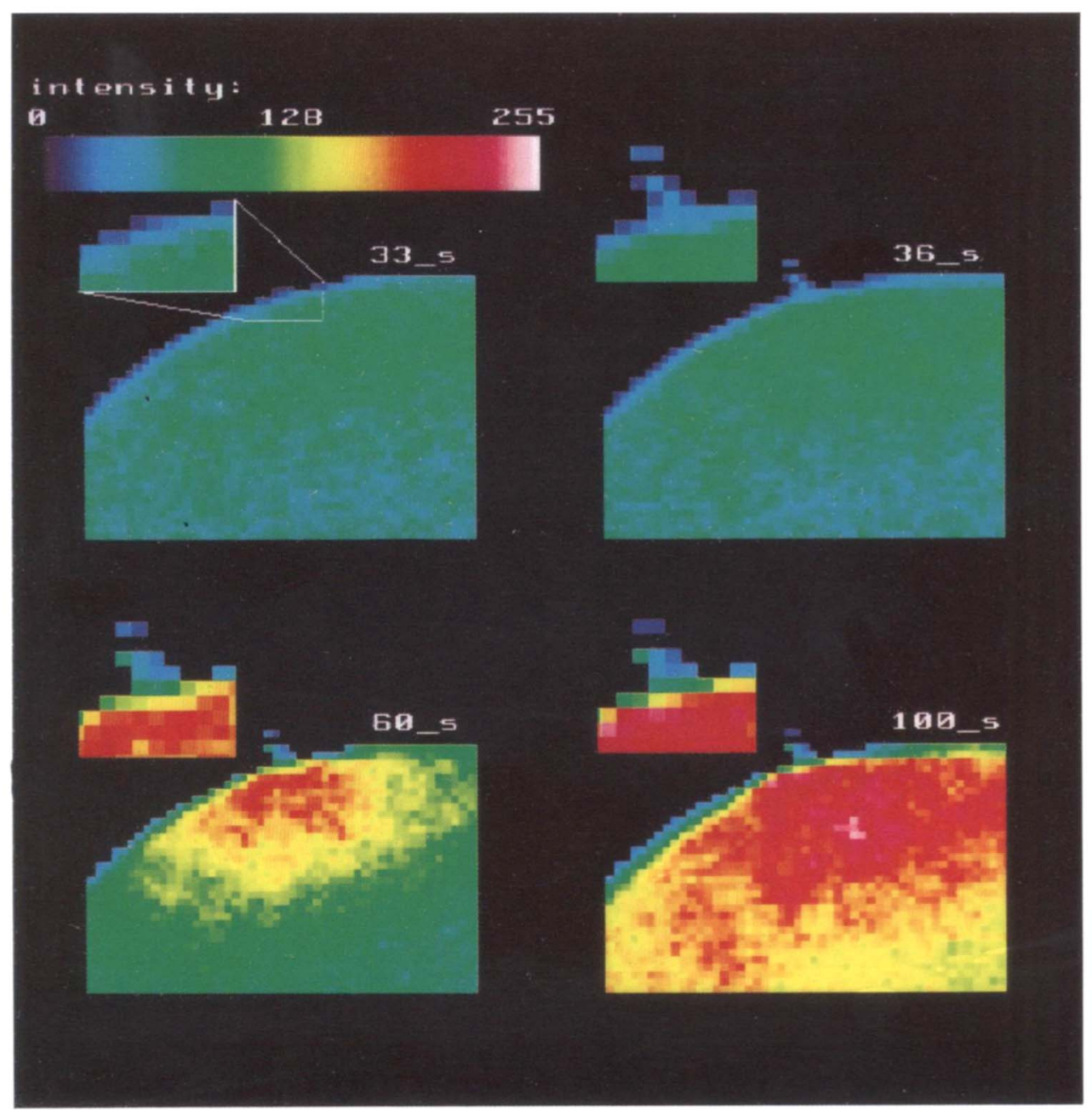

Figure 1. Sperm-egg fusion in the sea urchin at fertilization. Confocal image of changes in the cytoplasmic calcium concentration during fertilization in sea urchin eggs in equatorial section using the fluorescent indicator dye calcium green. Cold tones represent low intensities and warm tones high intensities. In the 3-s interval between the first and second images, dye has begun to diffuse from the egg into the sperm as cytoplasmic continuity is established. The third and fourth images show the initiation of the calcium wave. Pixels are $1 \mu \mathrm{m}$ square. 


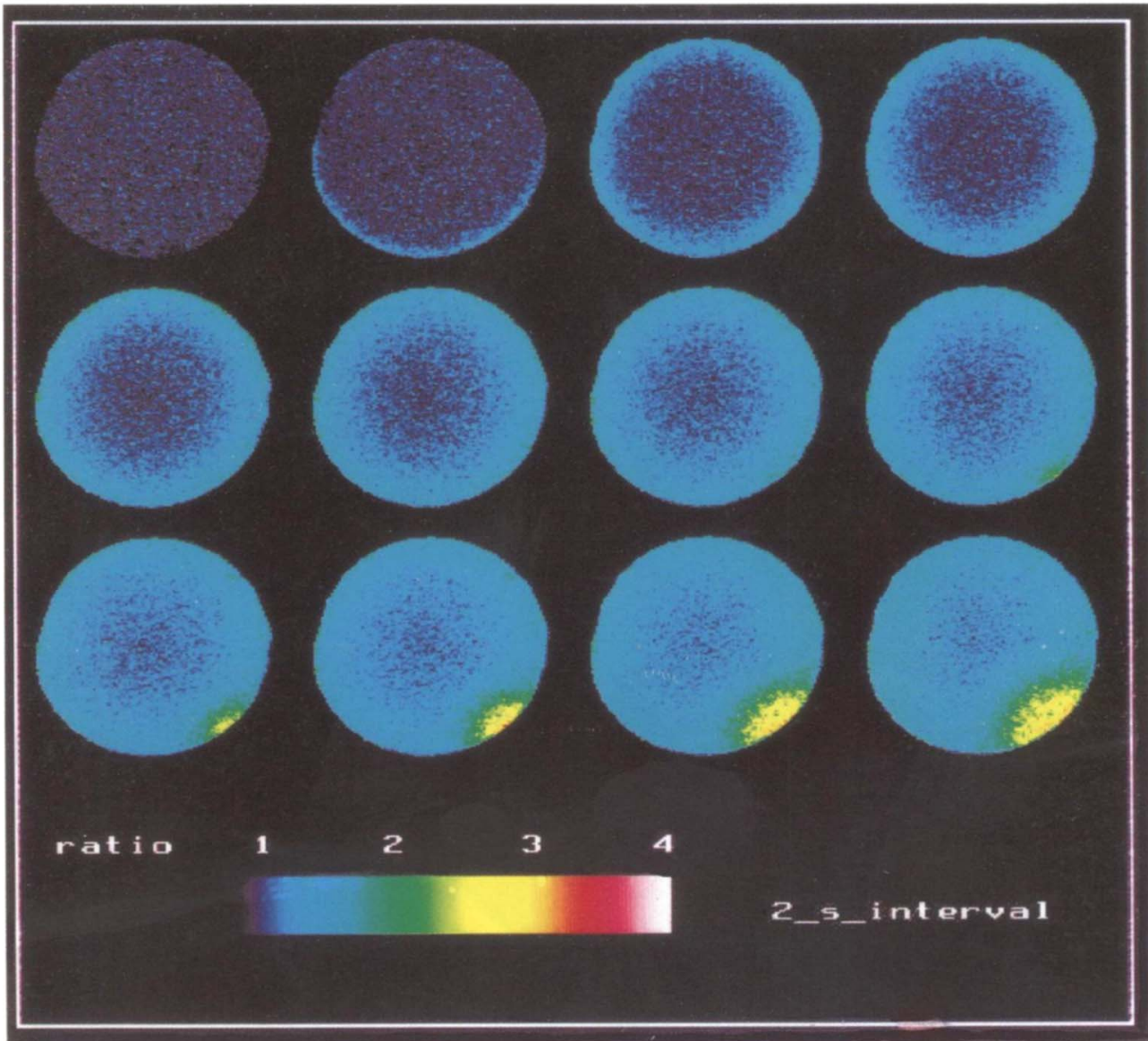

Figure 3. The latency of the fertilization response in the egg of the sea urchin, Lytechinus pictus $\left(16^{\circ} \mathrm{C}\right)$. Confocal ratio image of $\mathrm{Ca}_{\mathrm{i}}$ in the sea urchin egg at fertilization. Cold tones represent low $\mathrm{Ca}_{\mathrm{i}}$ and warm tones high $\mathrm{Ca}_{\mathrm{i}}$. The first detectable response at fertilization is seen at the egg periphery. The response is rapid and occurs within tens of milliseconds: the smile visible in the second image is an artefact due to influx beginning half-way through the confocal scan cycle. Each scan lasted $1 \mathrm{~s}$; there is a 1-s interval between scans. The influx occurs through voltage-gated calcium channels: it is sensitive to removal of external calcium and to calcium-channel blockers. It is due to the calcium action potential triggered by the sperm-induced depolarizing current that marks the beginning of the latent period (Whitaker et al., 1989). The calcium wave begins in the eighth image, $12 \mathrm{~s}$ after the initial sperm-egg interaction. This $12 \mathrm{~s}$ is the latent period. Ratio images were obtained by dividing each image, pixel by pixel, by a control image obtained at the beginning of the experiment, to give a signal independent of dye concentration. 
suggests that sperm-egg fusion is triggered when the egg answers the sperm by raising its intracellular calcium concentration. Figures 1 and 2 show the way in which a calcium indicator dye signal changes at fertilization in the region of sperm-egg fusion. Diffusion of the dye into the sperm from the egg cytoplasm precedes the calcium increase in the egg. A further increase in the dye signal may reflect a calcium increase in the sperm; this occurs after the calcium increase in the egg. This single observation is not consistent with the view that sperm-egg fusion is triggered by the egg's calcium transient. Nor does it support the view that calcium from the sperm sets off the egg's calcium wave (Jaffe, 1983, 1990), an idea known as the calcium bomb hypothesis. Also ranged against the idea of a calcium bomb are the observations that sperm incorporation is facilitated in sea urchin eggs when changes in calcium within the egg are prevented by injection of calcium chelators (Swann et al., 1992) or calcium channel blockers (McCulloh et al., 1989, 1990).

Despite the apparent shortcomings of the calcium bomb idea, sperm-egg fusion itself is more easily situated in the older (Loeb, 1913) model of fertilization: it must precede egg activation, since activation is said to be due to the diffusion of an activating messenger from sperm to egg through the cytoplasmic channel formed by the fusion of sperm and egg. Fusion must be a natural consequence of the binding of the sperm to its receptor, the receptor now being seen as analogous to cell adhesion receptors like the integrins, not to signalling receptors like those for 5-HT. The idea lacks strong support,

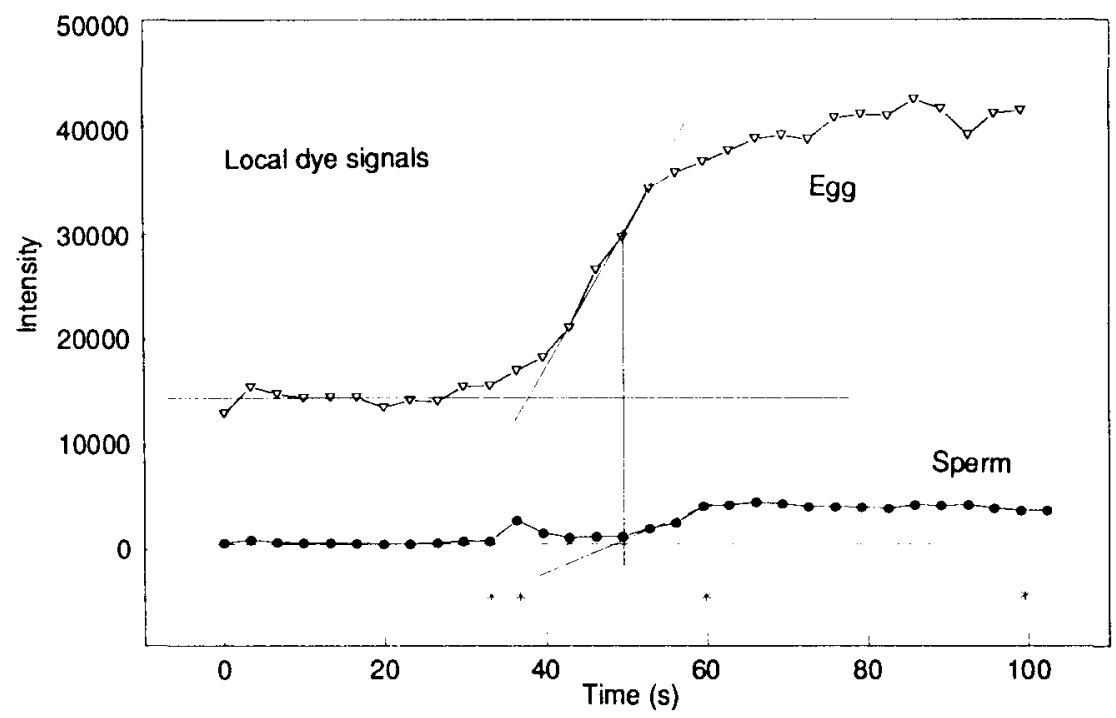

Figure 2. Sperm-egg fusion in the egg of the sea urchin, Lytechinus pictus $\left(16^{\circ} \mathrm{C}\right)$ at fertilization. The intensity signal from the eight pixels corresponding to the dye signal (Figure 1) from the sperm is compared with the signal from eight pixels just beneath the plasma membrane of the egg at the sperm entry site. The asterisks indicate the four images shown in Figure 1. The intensity signal measures both dye concentration and calcium concentration, though not independently. The comparison shows that dye transfer begins and ends before calcium starts to increase in the egg. There is a second increase in signal in the sperm that may correspond to a calcium increase in the sperm cytoplasm triggered by the increase in the egg. The latency of the fertilization response was artificially increased in this experiment by co-injecting heparin $\left(300 \mu \mathrm{g} \mathrm{ml}^{-1}\right)$ with the calcium green $(10 \mu \mathrm{M})$. Elapsed time from the beginning of data acquisition, some 2 min after insemination at very low sperm density $\left(<10^{5}\right.$ $\mathrm{ml}^{-1)}$, is shown. For methods see Galione et al. (1992). 
but it is not far-fetched: the guinea pig sperm-receptor protein contains a viral fusion peptide motif (Blobel et al., 1992) and bindin, the sperm acrosomal protein that binds to the sea urchin egg receptor, is fusogenic (Glabe, 1985a,b; Glabe et al., 1991; Lopez et al., 1993). The difficulties with the G-protein idea, particularly as applied to sea urchin eggs, have stimulated a re-investigation of the older model, with interesting and useful results.

\section{BREAKING AND ENTERING}

If indeed the sperm puts its shoulder to the door at fertilization without waiting for an answer from the egg, then sperm-egg fusion must precede the calcium wave. There is considerable latitude here, because the time between sperm-egg interaction and the onset of the calcium transient can be as long as seven minutes in mouse eggs (Jaffe et al., 1983), though in hamster eggs it is only a few seconds (Miyazaki \& Igusa, 1981). In mammals the length of this latent period is a property of the sperm: mouse sperm give rise to a seven minute latency when fertilizing hamster eggs (Igusa et al., 1983). The latency of the fertilization response has received most attention in sea urchin eggs, in part because it attracted early interest (Allen \& Griffen, 1958), but largely because the initial event at fertilization that marks the beginning of the latent period is easily recorded with precision in sea urchin eggs.

The first detectable event at fertilization in sea urchin eggs is an inward current with a very rapid onset (Dale et al., 1978). It precedes the fertilization calcium wave by 15-20 $\mathrm{s}$ and marks the moment of productive sperm-egg interaction, corresponding to the time at which fertilization can no longer be prevented by addition of spermicides (Whitaker et al., 1989), and to the point at which the electrical block to polyspermy (Jaffe, 1976) operates (Shen \& Steinhardt, 1984). There is a gap between sperm-egg interaction and egg activation. Allen \& Griffin (1958) first identified it as the $10-15 \mathrm{~s}$ period between the time that sperm cease to be susceptible to a spermicide like $\mathrm{KCl}$ and the time at which egg activation (FE elevation) occurs. They called it the latent period. The time that elapses between the current step and the calcium transient (Figure 3 ) is identical to the latent period defined by Allen \& Griffin (1958) and by other criteria (Whitaker $e$ t al., 1989; Swann et al., 1992). In an interesting series of technically-demanding experiments, Chambers and his colleagues estimated the time that elapsed between the current step and sperm-egg fusion. The initial approach was to fix single voltage-clamped sea urchin eggs chemically at various times after the current step was recorded. Once the eggs were fixed, fusion was assayed by monitoring dye diffusion from egg to sperm (Hinckley et al., 1986), or, even more remarkable, by taking serial thin sections of a single egg for analysis in the electron microscope (Longo et al., 1990). Cytoplasmic continuity (dye diffusion) is detected 4-8 s after the current step; fusion, as defined by continuity of gamete plasma membranes observed in the electron microscope, occurs $5 \mathrm{~s}$ or more after the step. That is, fusion clearly occurs before the onset of the calcium wave.

A later, more precise, approach dispensed with chemical fixation entirely and monitored fusion by measuring the electrical capacitance change that occurs in the egg 
membrane when cytoplasmic continuity is established between the gametes (McCulloh \& Chambers, 1992). The increase in membrane capacitance that signals fusion occurs at the same time as the current step, with a very rapid onset. Sperm-egg fusion, then, is fertilization, in the sense that it occurs at precisely the time that spermicides cease to be effective and at which the electrical polyspermy block operates.

\section{ONCE INSIDE}

\section{Cytoplasmic messengers}

A sperm using the muscular method to gain entry by fusion with an egg must then activate it. There is no consensus about what the activating agent may be, except that it must be present in the sperm as it fuses with the egg (Jaffe, 1983, 1990; Iwasa et al., 1990; Whalley et al., 1992). Calcium (Schackmann, 1989), InsP 3 (Iwasa et al., 1990) and cGMP (Kopf et al., 1979) all increase markedly in sea urchin sperm during the acrosome reaction just prior to fusion. Microinjection of $\mathrm{InsP}_{3}$ (Whitaker \& Irvine, 1984) and cGMP (Whalley et al., 1992) will activate the calcium wave in sea urchin eggs. Injection of calcium will not (Swann \& Whitaker, 1986). The most potent activating agent of this sort is cyclic ADP-ribose (cADPr; Clapper et al., 1987; Lee et al., 1989; Galione et al., 1991; Galione, 1992). It is not yet known whether it is present in sperm. cADPr has the advantage in potency: it is not clear if there is enough $\operatorname{InsP}_{3}$ or cGMP in sperm to trigger the calcium wave (Whitaker \& Swann, 1993). Remember also that the $\mathrm{InsP}_{3}$ antagonist heparin does not block fertilization in the sea urchin (Crossley et al., 1991). For the sea urchin sperm, cADPr looks the most likely, but perhaps only because least is known about it.

Hamster and frog eggs produce perfect regenerative calcium waves in response to calcium microinjection (Igusa \& Miyazaki, 1983; Busa \& Nuccitelli, 1985; Jaffe, 1990), showing classical calcium-induced calcium release (CICR: Endo, 1977; Fabiato, 1985). In these eggs, fertilization is blocked by $\mathrm{InsP}_{3}$ antagonists (Miyazaki et al., 1992; Galione et al., 1992). Calcium is elevated in mammalian sperm at fertilization, as is $\mathrm{InsP}_{3}$ (Florman et al., 1989); a case for either or both as the activating messenger clearly exists in frog or hamster, where, at least for the latter egg, neither cGMP nor cADPr is effective (Swann, unpublished observations). But mammalian eggs offer a new idea: the suggestion that the activating messenger at fertilization is a protein (Swann \& Whitaker, 1990; Swann, 1990).

The protein factor is isolated from sperm cytosol and triggers the repetitive and persistent calcium oscillations that are a peculiar feature of fertilization in hamster eggs (Miyazaki et al., 1986, 1993). This is interesting, because none of the other agents that elicit calcium responses in the hamster egg (calcium itself, InsP ${ }_{3}, \mathrm{GTP} \gamma \mathrm{S}$ ) reproduce the longevity of the response seen at fertilization and with the protein factor. The factor is unique, too, among the cytoplasmic messengers in mimicking the sensitization of CICR (Igusa \& Miyazaki, 1983) which accompanies fertilization (Swann, 1990; Swann, 1991; Whitaker \& Swann, 1993).

Which, if any, of these cytoplasmic messengers is responsible for triggering the 
fertilization calcium response is one question that awaits an answer. The other question is how the calcium wave, once begun, spreads across the egg.

\section{Calcium waves}

Calcium waves are highly explosive, both in eggs (Jaffe, 1980) and in somatic cells (Berridge \& Galione, 1988; Jacob, 1990). The positive feedback that precipitates the explosion appears to be an intrinsic property of the calcium release channels that rapidly dump calcium from its membrane store into the cytoplasm. These channels undergo calcium-induced calcium release (CICR). The classical CICR of muscle (Endo, 1977) is mediated by the so-called ryanodine receptor (RYR) (Lai et al., 1988; Takeshima et al., 1989). A novel form of CICR (Finch et al., 1991; Bezprovzanny et al., 1991; Missiaen et al., 1991) has been demonstrated with the $\mathrm{InsP}_{3}$ receptor, where calcium increases the affinity of the receptor for InsP $\mathrm{P}_{3}$. The Ins $\mathrm{P}_{3} \mathrm{R}$ is very closely related structurally to the RYR (Ross et al., 1989; Furuichi et al., 1989; Mignery et al., 1989; Südhof et al., 1991). There is a functional parallel, too, with the suggestion that the RYR is the target of the calcium mobilizing agent cADPr (Galione et al., 1991; Galione, 1992). Either of the two calcium release channels might sustain the calcium wave at fertilization. Which is it?

There are two approaches to the question, one descriptive, the other functional. The descriptive approach has demonstrated the presence of $\mathrm{InsP}_{3} \mathrm{R}$ in hamster eggs (Miyazaki et al., 1992) and Xenopus oocytes (Parys et al., 1992) and of RYR in sea urchin (McPherson et al., 1992). The functional approach uses agonists and antagonists of the two channels and is perhaps more informative. The results are summarized in Table 1. To précis them further: $\mathrm{Ins}_{3} \mathrm{R}$ are functionally active in frog, mouse, hamster and sea urchin eggs. $\mathrm{RYR}$

Table 1 . The Ins $P_{3}$ receptor and the ryanodine receptor.

\begin{tabular}{|c|c|c|c|c|}
\hline & Frog & Mouse & Hamster & Sea urchin \\
\hline \multicolumn{5}{|l|}{ Agonists that cause $\mathrm{Ca}^{2+}$ release } \\
\hline $\mathrm{InsP}_{3}$ & $t^{i}$ & $t^{2}$ & $t^{3}$ & $t^{4}$ \\
\hline cADPr & -5 & -6 & .7 & $t^{8}$ \\
\hline ryanodine & -5 & $t^{2}$ & $?$ & $t^{9}$ \\
\hline caffeine & .5 & -2 & -10 & +11 \\
\hline \multicolumn{5}{|c|}{ Antagonists that block CICR/fertilization } \\
\hline heparin & $t^{5}$ & ? & $?$ & -5 \\
\hline InsP $P_{3}$ sponge $/$ Ins $P_{3} R A b$ & $++^{12}$ & $?$ & +13 & -14 \\
\hline ryanodine & $?$ & $+^{2}$ & $?$ & $?$ \\
\hline ruthenium red & - & $?$ & $?$ & -5 \\
\hline heparin + ruthenium red & $?$ & $?$ & $?$ & $+^{5}$ \\
\hline \multicolumn{5}{|l|}{ Conclusion } \\
\hline RYR & - & $+1-$ & ? & + \\
\hline $\operatorname{Ins} P_{3} R$ & + & + & + & + \\
\hline
\end{tabular}


are active in sea urchin and mouse eggs and, possibly, in hamster, though the RYR in mammalian eggs does not respond to either caffeine or cADPr.

The frog egg is insensitive to RYR agonists and antagonists. The prediction that CICR in the frog egg is mediated by $\operatorname{InsP}_{3} \mathrm{R}$ is borne out by the observation that the $\operatorname{InsP}_{3}$ antagonist, heparin, blocks CICR in frog eggs (Galione et al., 1993). When heparin is micro-injected into frog eggs, it blocks not only CICR but the fertilization calcium wave, too. It now seems fairly certain that the fertilization calcium wave in the frog is based on InsP $\mathrm{P}_{3} \mathrm{R}$-CICR, as are the small calcium waves that can be induced artificially in immature frog oocytes (Lechleiter \& Clapham, 1992). The sea urchin, on the other hand, has both functional InsP $\mathrm{I}_{3} \mathrm{R}$ and RYR (Fujiwara et al., 1990). Agonists of either receptor trigger a regenerative calcium response and antagonists to either channel block CICR only when present together (Galione et al., 1992; Lee et al., 1993). The fertilization calcium wave is effectively blocked only when antagonists of both channel types are present. It now seems that the fertilization calcium wave in the sea urchin relies on both RYR-CICR and InsP ${ }_{3} R-C I C R$. Mammalian eggs resemble the frog egg in having a CICR and fertilization wave that is blocked by an InsP ${ }_{3}$ antagonist (Miyazaki et al., 1992, 1993). We could take it that the hamster fertilization wave is generated solely by InsP $_{3} \mathrm{R}-\mathrm{CICR}$, were it not that ryanodine, the idiotypic $R Y R$ agonist, causes regenerative calcium oscillations in mouse eggs and inhibits the mouse egg's periodic calcium oscillations when they are generated by other means (Swann, 1992). It is possible that while RYRCICR cannot alone sustain a calcium wave in mammalian eggs, it nonetheless contributes to the calcium wave, enhancing InsP $\mathrm{P}_{3} \mathrm{R}-\mathrm{CICR}$.

\section{Putting two and two together}

One interesting outcome of these recent experiments is the realization that an apparently identical phenomenon, the fertilization calcium wave (Jaffe, 1983), may show a multiplicity of mechanisms in different eggs. In the sea urchin, two CICR channels, InsP $\mathrm{P}_{3} \mathrm{R}$ and $\mathrm{RYR}$, contribute to the wave and generate a richness of choice: any or all of calcium, InsP ${ }_{3}$, cADPr and cGMP may co-operate to initiate the calcium wave. In the frog egg, the sole participation of the $\operatorname{InsP}_{3} \mathrm{R}$ narrows our choice: calcium or $\operatorname{InsP}_{3}$. The mammalian egg lies somewhere in between. Each egg may be different.

Or we can point to similarities. It used to be said that CICR existed in frog (Busa et al., 1985) and hamster (Igusa \& Miyazaki, 1983), but not in sea urchin eggs (Swann \& Whitaker, 1986). Now CICR is demonstrable in all as the mediator of the fertilization calcium wave. Another possible unity of mechanism is suggested by the observation that the activating factor from hamster sperm cytoplasm triggers calcium release in both frog and sea urchin homogenates (Galione and Swann, unpublished observations). There is convergence as well as divergence here.

There are still two models of fertilization, one involving $\mathrm{G}$ proteins and InsP $\mathrm{P}_{3}$, the other fusion and a cytoplasmic messenger. They offer the possibility of a clear choice, but we are still waiting for the information that will give us a final answer. 
Our work is supported by the Wellcome Trust, the Royal Society, the Science and Engineering Research Council and the Medical Research Council. A.D. was an SERC Scholar.

\section{REFERENCES}

Allen, R.D. \& Griffin, J.L., 1958. The time sequence of early events at fertilization of sea urchin eggs. Experimental Cell Research, 12, 163-173.

Berridge, M.J. \& Galione, A., 1988. Cytosolic calcium oscillators. FASEB Journal, 2, 3074-3082.

Bezprovzanny, I., Watras, J. \& Erlich, B.E., 1991. Bell-shaped calcium response of Ins $(1,4,5) \mathrm{P}_{3}$ - and calcium-gated channels from endoplasmic reticulum. Nature, London, 351, 751-754.

Blobel, C.P., Wolfsberg, T.G., Turck, C.W., Myles, D.G., Primakoff, P. \& White, J.M., 1992. A potential fusion peptide and an integrin ligand domain in a protein active in sperm-egg fusion. Nature, London, 356, 248-252.

Buck, R.W., Rakow, T.L. \& Shen, S.S., 1992. Synergistic release of calcium in sea urchin eggs by caffeine and ryanodine. Experimental Cell Research, 202, 59-66.

Busa, W.B., Ferguson, J.E., Suresh, K.J., Williamson, J.R. \& Nuccitelli, R., 1985. Activation of frog (Xenopus laevis) eggs by inositol trisphosphate. I. Characterization of $\mathrm{Ca}^{2+}$ release from intracellular stores. Journal of Cell Biology, 101, 677-682.

Busa, W.B. \& Nuccitelli, R., 1985. An elevated free cytosolic $\mathrm{Ca}^{2+}$ wave follows fertilization in eggs of the frog Xenopus laevis. Journal of Cell Biology, 100, 1325-1329.

Chambers, E.L., 1989. Fertilization in voltage-clamped sea urchin eggs. In Mechanisms of egg activation (ed. R. Nuccitelli et al.), pp. 1-18. New York: Plenum Press.

Ciapa, B., Borg, B. \& Epel, D., 1991. Polyphosphoinosites, tyrosine kinase and sea urchin egg activation. In Proceedings of the Seventh International Echinoderm Conference. Biology of the Echinodermata (ed. Y. Yanagisawa et al.), pp. 41-50. Rotterdam: A.A. Balkema.

Ciapa, B., Borg, B. \& Whitaker, M.J., 1992. Polyphosphoinositide metabolism during the fertilization wave in sea urchin eggs. Development, 115, 187-195.

Ciapa, B. \& Whitaker, M.J., 1986. Two phases of inositol polyphosphate and diacylglycerol production at fertilization. FEBS Letters, 195, 347-351.

Clapper, D.L., Walseth, T.F., Dargie, P.J. \& Lee, H.-C., 1987. Pyridine nucleotide metabolites stimulate calcium release from sea urchin egg microsomes desensitized to inositol trisphosphate. Journal of Biological Chemistry, 262, 9561-9568.

Cran, D.G., Moor, R.M. \& Irvine, R.F., 1988. Initiation of the cortical reaction in hamster and sheep oocytes in response to inositol trisphosphate. Journal of Cell Science, 91, 139-144.

Crossley, I., Swann, K., Chambers, E.L. \& Whitaker, M.J., 1988. Activation of sea urchin eggs by inositol phosphates is independent of external calcium. Biochemical Journal, 252, 257-262.

Crossley, I., Whalley, T. \& Whitaker, M.J., 1991. Guanosine 5'-thiotriphosphate may stimulate phosphoinositide messenger production in sea urchin eggs by a different route than the fertilizing sperm. Cell Regulation, 2, 121-133.

Dale, B., DeFelice, L.J. \& Taglietti, V. 1978. Membrane noise and conductance increase during single spermatozoon-egg interactions. Nature, London, 275, 217-219.

Endo, M., 1977. Calcium release from the sarcoplasmic reticulum. Physiological Reviews, 57, 71108.

Fabiato, A., 1985. Stimulated calcium current can both cause calcium loading in and trigger calcium release from the sarcoplasmic reticulum of a skinned cardiac Purkinje cell. Journal of General Physiology, 85, 291-320.

Finch, E.A., Turner, T.J. \& Goldin, S.M., 1991. Calcium as a coagonist of inositol 1,4,5-trisphosphate induced calcium release. Science, New York, 252, 443-446.

Florman, H.M., Tombes, R.M., First, N.L. \& Babcock, D.F., 1989. An adhesion-associated agonist from the zona pellucida activates $G$ protein-promoted elevations of intracellular calcium and $\mathrm{pH}$ that mediate mammalian sperm acrosomal exocytosis. Developmental Biology, 135, 133-146.

Foltz, K.R. \& Lennarz, W.J., 1990. Purification and characterization of an extracellular fragment of the sea urchin receptor for sperm. Journal of Cell Biology, 111, 2951-2959. 
Foltz, K.R. \& Lennarz, W.J., 1992. Identification of the sea urchin egg receptor for sperm using an antiserum raised against a fragment of its extracellular domain. Journal of Cell Biology, 116, 647-658.

Foltz, K.R., Partin, J.S. \& Lennarz, W.J., 1993. Sea urchin egg receptor for sperm: sequence similarity of binding domain and hsp70. Science, New York, 259, 1421-1425.

Fujiwara, A., Taguchi, K. \& Yasumasu, I., 1990. Fertilization membrane formation in sea urchin eggs induced by drugs known to cause $\mathrm{Ca}^{2+}$ release from isolated sarcoplasmic reticulum. Development, Growth and Differentiation, 32, 303-314.

Furuichi, T., Yoshikawa, S., Miyawaki, A., Wada, K., Maeda, N. \& Mikoshiba, K., 1989. Primary structure and functional expression of the inositol 1,4,5-trisphosphate-binding protein P400. Nature, London, 342, 32-38.

Galione, A., 1992. Calcium-induced calcium release and its modulation by cyclic ADP-ribose. Trends in Pharmacological Science, 13, 304-307.

Galione, A., Lee, H.C. \& Busa, W.B., 1991. $\mathrm{Ca}^{2+}$-induced $\mathrm{Ca}^{2+}$ release in sea urchin egg homogenates: modulation by cyclic ADP-ribose. Science, New York, 253, 1143-1146.

Galione, A., McDougall, A., Busa, W.B., Willmott, N., Gillot, I. \& Whitaker, M.J., 1993. Redundant mechanisms of calcium-induced calcium release underlying calcium waves during fertilization of sea urchin eggs. Science, New York, 261, 348-352.

Ghosh, T.R., Mullaney, G.M., Terazi, F.I. \& Gill, D.L., 1989. GTP-activated communication between distinct inositol 1,4,5-trisphosphate-sensitive and -insensitive calcium pools. Nature, London, 340, 236-239.

Glabe, C.G., 1985a. Interaction of the sperm adhesive protein, bindin, with phospholipid vesicles. I. Specific association of bindin with gel-phase phospholipid vesicles. Journal of Cell Biology, 100, 794-799.

Glabe, C.G., 1985b. Interaction of the sperm adhesive protein, bindin, with phospholipid vesicles. II. Bindin induces the fusion of mixed-phase vesicles that contain phosphatidylcholine and phosphatidylserine in vitro. Journal of Cell Biology, 100, 800-806.

Glabe, C.G., Hong, K. \& Vacquier, V.D., 1991. Fusion of sperm and egg plasma membranes during fertilization. In Membrane fusion (ed. J. Wilschut and D. Hoekstra), pp. 627-646. New York: Dekker.

Henson, J.H., Beaulieu, S.M., Kaminer, B. \& Begg, D.A., 1990. Differentiation of a calsequestrincontaining endoplasmic reticulum during sea urchin oogenesis. Developmental Biology, 142, 255-269.

Henson, J.H., Begg, D.A., Beaulieu, S.M., Fishkind, D.J., Bonder, E.M., Terasaki, M., Lebeche, D. \& Kaminer, B., 1989. A calsequestrin-like protein in the endoplasmic reticulum of the sea urchin: localization and dynamics in the egg and first cell embryo. Journal of Cell Biology, 109, 149-161.

Hinckley, R.E., Wright, B.D. \& Lynn, J.W., 1986. Rapid visual detection of sperm-egg fusion using the DNA-specific fluorochrome Hoechst 33342. Developmental Biology, 118, 148-154.

Igusa, Y. \& Miyazaki, S., 1983. Effects of altered extracelluar and intracellular calcium concentration on hyperpolarizing responses of hamster egg. Journal of Physiology, 340, 611-632.

Igusa, Y., Miyazaki, S. \& Yamashita, N., 1983. Periodic hyperpolarizing responses in hamster and mouse eggs fertilized with mouse sperm. Journal of Physiology, 340, 643-647.

Iwasa, K.H., Ehrenstein, G., DeFelice, L.J. \& Russell, J.T., 1990. High concentrations of inositol 1,4,5-trisphosphate in sea urchin sperm. Biochemical and Biophysical Research Communications, 172, 932-938.

Jacob, R., 1990. Calcium oscillations in electrically non-excitable cells. Biochimica et Biophysica Acta, 1052, 427-458.

Jaconi, M.E.E., Theler, J.M., Schlegel, W., Appel, R.D., Wright, S.D. \& Lew. P.D., 1991. Multiple elevations of cytosolic free $\mathrm{Ca}^{2+}$ in human neutrophils: initiation by adherence receptors of the integrin family. Journal of Cell Biology, 112, 1249-1257.

Jaffe, L.A., 1976. Fast block to polyspermy in sea urchin eggs is electrically mediated. Nature, London, 261, 68-71.

Jaffe, L.A., Sharp, A.P. \& Wolf, D.P., 1983. Absence of an electrical block to polyspermy in the mouse. Developmental Biology, 96, 317-323. 
Jaffe, L.A., Turner, P.R., Kline, D., Kado, R.T. \& Shilling, F., 1988. G-proteins and egg activation. Cell Differentiation and Development, Supplement, 25, 15-18.

Jaffe, L.F., 1980. Calcium explosions as triggers of development. Annals of the New York Academy of Sciences, 339, 86-101.

Jaffe, L.F., 1983. Sources of calcium in egg activation: a review and hypothesis. Developmental Biology, 99, 265-276.

Jaffe, L.F., 1990. The roles of intermembrane calcium in polarizing and activating eggs. In Mechanisms of fertilization: plants to humans (ed. B. Dale), pp. 389-417. Berlin: Springer Verlag. [Nato ASI Series H, Cell Biology 45.]

Jaffe, L.F., 1991. The path of calcium in cytosolic calcium oscillations: a unifying hypothesis. Proceedings of the National Academy of Sciences of the United States of America, 88, 9883-9887.

Kline, D. \& Kline, J.T., 1992. Effects of microinjection of inositol 1,4,5-trisphosphate on the repetitive calcium transients and the role of calcium in exocytosis and cell cycle control in the mouse egg. Developmental Biology, 145, 80-89.

Kline, D., Kopf, G.S., Muncy, L.F. \& Jaffe, L.A., 1991. Evidence for the involvement of a pertussis toxin-insensitive G-protein in egg activation of the frog, Xenopus laevis. Developmental Biology, 143, 218-229.

Kline, D., Simoncini, L., Mandel, G., Maue, R.A., Kado, R.T. \& Jaffe, L.A., 1988. Fertilization events induced by neurotransmitters after injection of mRNA in Xenopus eggs. Science, New York, 241, 464-467.

Kopf, G.S., Tubb, D.J., \& Garbers, D.L., 1979. Activation of sperm respiration by a low molecular weight egg factor and by 8-bromoguanosine 3',5'-monophosphate. Journal of Biological Chemistry, 254, 8554-8560.

Kornberg, L.J., Earp, H.S., Turner, C.E., Prokop, C. \& Juliano, R.L., 1991. Signal transduction by integrins: increased protein phosphorylation caused by clustering of $\beta_{1}$ integrins. Proceedings of the National Academy of Sciences of the United States of America, 88, 8392-8396.

Kurasawa, S., Schultz, R.M. \& Kopf, G.S., 1989. Egg-induced modifications of the zona pellucida of mouse eggs: effects of microinjected inositol 1,4,5-trisphosphate. Developmental Biology, 133, 295-304.

Lai, F.A., Erickson, H.P., Rousseau, E., Lin, Q.Y. \& Meissner, G., 1988. Purification and reconstitution of the calcium-release channel from skeletal muscle. Nature, London, 331, 315-319.

Lechleiter, J.D. \& Clapham, D.E., 1992. Molecular mechanisms of intracellular calcium excitability in Xenopus laevis oocytes. Cell, 69, 283-294.

Lee, H.C., Aarhus, R. \& Walseth, T.F., 1993. Calcium mobilization by dual receptors during fertilization of sea urchin eggs. Science, New York, 261, 352-355.

Lee, H.C., Walseth, T.F., Bratt, G.T., Hayes, R.N. \& Clapper, D.L., 1989. Structural determination of a cyclic metabolite of NAD+ with intracellular $\mathrm{Ca}^{2+}$-mobilizing activity. Journal of Biological Chemistry, 264, 1608-1615.

Loeb, J., 1913. Artificial parthenogenesis and fertilization. Chicago: University of Chicago Press.

Longo, F.J., 1978. Effects of cytochalasin B on sperm-egg interactions. Developmental Biology, 67, 249-265.

Longo, F., Cook, S., McCulloh, D., Ivonnet, P. \& Chambers, E.L., 1990. Gamete interaction and the initiation of egg activation in sea urchins. In Mechanisms of fertilization: plants to humans (ed. B. Dale), pp. 389-417. Berlin: Springer Verlag. [Nato ASI Series H, Cell Biology 45.]

Longo, F.J., Lynn, J.W., McCulloh, D.H. \& Chambers, E.L., 1986. Correlative ultrastructural and electrophysiological studies of sperm-egg interactions of the sea urchin, Lytechnus variegatus. Developmental Biology, 118, 155-166.

Lopez, A., Miraglia, S.J. \& Glabe, C.G., 1993. Structure/function analysis of the sea urchin sperm adhesive protein bindin. Developmental Biology, 156, 24-33.

Lorca, T., Galas, S., Fesquet, D., Devault, A., Cavadore, J.C. \& Doree, M., 1991. Degradation of the proto-oncogene product $\mathrm{p} 38^{\mathrm{mos}}$ is not necessary for cyclin proteolysis and exit from meiotic metaphase: requirement for a $\mathrm{Ca}^{2+}$-calmodulin dependent event. EMBO Journal, 10, 20872093. 
McCulloh, D.H. \& Chambers, E.L., 1992. Fusion of membranes during fertilization: increases of sea urchin egg's membrane capacitance and membrane conductance at the site of contact with the sperm. Journal of General Physiology, 99, 137-175.

McCulloh, D.H., Ivonnet, P.I. \& Chambers, E.L., 1989. Blockers of Ca influx promote sperm entry in sea urchin eggs at clamped negative membrane potentials. Journal of Cell Biology, 109, 126a.

McCulloh, D.H., Ivonnet, P.I. \& Chambers, E.L., 1990. Microinjection of a $\mathrm{Ca}^{2+}$ chelator, EGTA and BAPTA promotes sperm entry in sea urchin eggs clamped at negative potentials. Journal of Cell Biology, 111, 113a.

McPherson, S.M., McPherson, P.S., Matthews, L., Campbell, K.P. \& Longo, F.J., 1992. Cortical localization of calcium release channel in sea urchin eggs. Journal of Cell Biology, 116, 11111121.

Mignery, G.A., Südhof, T.C., Takei, K. \& De Camilli, P., 1989. Putative receptor for inositol 1,4,5trisphosphate similar to ryanodine receptor. Nature, London, 342, 192-195.

Missiaen, L., Taylor, C.W. \& Berridge, M.J., 1991. Spontaneous calcium release from inositol trisphosphate-sensitive calcium stores. Nature, London, 352, 241-244.

Miyazaki, S., 1988. Inositol 1,4,5-trisphosphate-induced calcium release and guanine nucleotidebinding protein-mediated periodic calcium rises in golden hamster eggs. Journal of Cell Biology, 106, 345-353.

Miyazaki, S., Hashimoto, N., Yoshimoto, Y., Kishimoto, T., Igusa, Y. \& Hiramoto, Y., 1986. Temporal and spatial dynamics of the periodic increase in intracellular calcium at fertilization of golden hamster eggs. Developmental Biology, 118, 259-267.

Miyazaki, S. \& Igusa, Y., 1981. Fertilization potential in golden hamster eggs consists of recurring hyperpolarizations. Nature, London, 290, 706-707.

Miyazaki, S., Katayama, Y. \& Swann, K., 1990. Synergistic activation by serotonin and GTP analogue and inhibition by phorbol ester of cyclic $\mathrm{Ca}^{2+}$ rises in hamster eggs. Journal of Physiology, 426, 209-227.

Miyazaki, S., Shirakawa, H., Nakada, K. \& Honda, Y., 1993. Essential role of the inositol 1,4,5trisphosphate receptor $/ \mathrm{Ca}^{2+}$ release channel in $\mathrm{Ca}^{2+}$ waves and $\mathrm{Ca}^{2+}$ oscillations at fertilization of mammalian eggs. Developmental Biology, 158, 62-78.

Miyazaki, S., Yuzaki, M., Nakada, K., Shirakawa, H., Nakanishi, S., Nakade, S. \& Mikoshiba, K., 1992. Block of $\mathrm{Ca}^{2+}$ wave and $\mathrm{Ca}^{2+}$ oscillation by antibody to the $\mathrm{IP}_{3}$ receptor in fertilized hamster eggs. Science, New York, 257, 251-255.

Parys, J.B., Sernett, S.W., DeLisle, S., Snyder, P.M., Welsh, M.J. \& Campbell, K.P., 1992. Isolation, characterization and localization of the inositol 1,4,5-trisphosphate receptor protein in Xenopus laevis oocytes. Journal of Biological Chemistry, 267, 18776-18782.

Rakow, T.L. \& Shen, S.S., 1990. Multiple stores of calcium are released in the sea urchin egg during fertilization. Proceedings of the National Academy of Sciences of the United States of America, 87, 9285-9289.

Rhee, S.G., 1991. Inositol phospholipids-specific phospholipase C: interaction of the gamma isoform with tyrosine kinase. Trends in Biochemical Science, 16, 297-301.

Ross, C.A., Meldolesi, J., Milner, T.A., Satoh, T., Supattopone, S. \& Snyder, S.H., 1989. Inositol 1,4,5-trisphosphate receptor localised to endoplasmic reticulum in cerebellar Purkinje neurones. Nature, London, 339, 468-470.

Sardet, C., Gillot, I., Ruscher, A., Payan, P., Girard, J.-P. \& Renzis, G. de, 1992. Ryanodine activates sea urchin eggs. Development, Growth and Differentiation, 34, 37-42.

Schackmann, R.W., 1989. Ionic regulation of the sea urchin sperm acrosome reaction and stimulation by egg-derived peptides. In The cell biology of fertilization (ed. H. Schatten and G. Schatten). San Diego: Academic Press.

Sealfon, S.C., Mundamattom, S. \& Gillo, B., 1990. Modulation of calcium mobilization by guanosine 5'-O-(2-thiodiphosphate) in Xenopus oocytes. FEBS Letters, 269, 135-138.

Shen, S.S. \& Steinhardt, R.A., 1984. Time and voltage windows for reversing the electrical block to fertilization. Proceedings of the National Academy of Sciences of the United States of America, 81, 1436-1439.

Shilling, F., Chiba, K., Hoshi, M., Kishimoto, T. \& Jaffe, L.A., 1989. Pertussis toxin inhibits 1methyladenine-induced maturation in starfish oocytes. Developmental Biology, 133, 605-608. 
Shilling, F., Mandel, G. \& Jaffe, L.A., 1990. Activation by serotonin of starfish eggs expressing the rat serotonin 1c receptor. Cell Regulation, 1, 465-469.

Steinhardt, R.A., Epel, D., Caroll, E.J. \& Yanagimachi, R., 1974. Is calcium ionophore a universal activator for unfertilised eggs? Nature, London, 252, 41-43.

Südhof, T.C., Newton, C.L., Archer, B.T., III, Ushkaryov, Y.A. \& Mignery, G.A., 1991. Structure of a novel InsP $\mathrm{P}_{3}$ receptor. EMBO Journal, 10, 3199-3206.

Swann, K., 1990. A cytosolic sperm factor stimulates repetitive calcium increases and mimics fertilization in hamster eggs. Development, 110, 1295-1302.

Swann, K., 1991. Thimerosal causes calcium oscillations and sensitizes calcium-induced calcium release in unfertilized hamster eggs. FEBS Letters, 278, 175-178.

Swann, K., 1992. Different triggers for $\mathrm{Ca}^{2+}$ oscillations in mouse eggs involve a ryanodinesensitive calcium store. Biochemical Journal, 287, 79-84.

Swann, K., Igusa, I. \& Miyazaki, S., 1989. Evidence for an inhibitory effect of protein kinase C on G-protein-mediated repetitive calcium transients in hamster eggs. EMBO Journal, 8, 37113718.

Swann, K., McCulloh, D.H., McDougall, A., Chambers, E.L. \& Whitaker, M.J., 1992. Sperminduced currents at fertilization in sea urchin eggs injected with EGTA and neomycin. Developmental Biology, 151, 552-563.

Swann, K. \& Whitaker, M.J., 1986. The part played by inositol trisphosphate and calcium in the propagation of the fertilization wave in sea urchin eggs. Journal of Cell Biology, 103, 2333-2342.

Swann, K. \& Whitaker, M.J., 1990. Second messengers at fertilization in sea-urchin eggs. Journal of Reproduction and Fertilization, Supplement, 42, 141-153.

Takeshima, H., et al., 1989. Primary structure and expression from complementary DNA of skeletal muscle ryanodine receptor. Nature, London, 339, 439-445.

Terasaki, M., Henson, J., Begg, D., Kaminer, B. \& Sardet, C., 1991. Characterization of sea urchin egg endoplasmic reticulum in cortical preparations. Developmental Biology, 148, 398-401.

Terasaki, M. \& Sardet, C., 1991. Demonstration of calcium uptake and release by sea urchin egg cortical endoplasmic reticulum. Journal of Cell Biology, 115, 1031-1037.

Turner, P.R., Jaffe, L.A. \& Fein, A., 1986. Regulation of cortical granule exocytosis by inositol 1,4,5trisphosphate and GTP binding protein. Journal of Cell Biology, 102, 70-76.

Turner, P.R., Jaffe, L.A. \& Primakoff, P., 1987. A cholera-toxin sensitive G-protein stimulates exocytosis in sea urchin eggs. Developmental Biology, 120, 577-583.

Turner, P.R., Sheetz, M.P. \& Jaffe, L.A., 1984. Fertilization increases the polyphosphoinositides content of sea urchin eggs. Nature, London, 310, 414-415.

Whalley, T., McDougall, A., Crossley, I., Swann, K. \& Whitaker, M.J., 1992. Internal calcium release and activation of sea urchin eggs by cGMP are independent of the phosphoinositide signalling pathway. Molecular Biology of the Cell, 3, 373-383.

Whitaker, M.J. \& Aitchison, M.J., 1985. Calcium-dependent polyphosphoinositide hydrolysis is associated with exocytosis in vitro. FEBS Letters, 182, 119-124.

Whitaker, M.J. \& Irvine, R.F., 1984. Micro-injection of inositol trisphosphate activates sea urchin eggs. Nature, London, 312, 636-638.

Whitaker, M.J. \& Patel, R., 1990. Calcium and cell cycle control. Development, 108, 525-542.

Whitaker, M.J. \& Steinhardt, R.A., 1982. Ionic regulation of egg activation. Quarterly Reviews of Biophysics, 15, 593-666.

Whitaker, M.J. \& Swann, K., 1993. Lighting the fuse at fertilization. Development, 117, 1-12.

Whitaker, M.J., Swann, K. \& Crossley, I.B., 1989. What happens during the latent period at fertilization in sea urchin eggs? In Mechanisms of egg activation (ed. R. Nuccitelli), pp. 159-163. New York: Plenum Press.

Williams, C.J., Schultz, R.M. \& Kopf, G.S., 1992. Role of G-proteins in mouse egg activation: stimulatory effects of acetyl choline on the $\mathrm{ZP} 2$ to $\mathrm{ZP} 2 \mathrm{f}$ conversion and pronuclear formation in eggs expressing a functional m1 muscarinic receptor. Developmental Biology, 151, 288-296. 